\title{
Immunopathological changes in rheumatoid arthritis and other joint diseases
}

\author{
T. GHOSE, J. F. L. WOODBURY, S. AHMAD, AND BETH STEVENSON \\ From the Departments of Medicine, Pathology, Microbiology and Immunology, Dalhousie University, \\ and the Rheumatic Disease Unit, Victoria General Hospital, Halifax, Nova Scotia, Canada
}

SYNOPSIS A comparative study of the distribution of immunoglobulins $\mathbf{G}, \mathbf{M}$, and $A$ and $\mathbf{C} 3$ in the synovium and inside synovial fluid leucocytes and of the relative levels of IgG, IgM, and C3 in paired samples of serum and synovial fluid from both seropositive and seronegative patients with rheumatoid arthritis and other types of non-infective synovitis shows that although there is no distinctive immunopathological feature of rheumatoid arthritis, the incidence of immune complexes containing IgG and IgM with and without detectable C3 in the affected synovium or inside synovial fluid granulocytes is higher in rheumatoid arthritis and especially so in seropositive cases. The mean level of C3 in synovial fluid from patients with rheumatoid arthritis is lower than that from the group without rheumatoid arthritis. In contrast to previous reports, extracellular clumps of $\operatorname{IgA}$ could be detected in the affected synovium of a number of affected patients. Aggregated human IgG could be bound by some of the synovial biopsies and synovial fluid leucocytes from both seropositive and seronegative rheumatoid arthritis patients. Antinuclear factor and rheumatoid factor could be detected in the synovial fluid but not in the serum of several patients suggesting either selective sequestration or local synthesis of antinuclear and rheumatoid factors in the affected joints.

Immunological mechanisms have been implicated in the induction and maintenance of the rheumatoid inflammatory process mainly based upon observations that: (1) immunoglobulins, including rheumatoid factor, are locally produced by plasma cells in the rheumatoid synovium; (2) that complexes containing immunoglobulins and complement are present in rheumatoid synovium, synovial fluid, and synovial polymorphonuclear leucocytes; and (3) that the level of complement in rheumatoid joint effusions is usually lower than the level of complement in the patient's serum or in synovial effusions caused by diseases other than rheumatoid arthritis (Zvaifler, 1973; Ziff, 1973; Ruddy and Austen, 1973).

We present here the results of a comparative immunopathological study of the synovium and synovial fluid from seropositive and seronegative rheumatoid arthritis and other non-infective arthritis patients from whom samples of serum, synovial fluid, and synovial tissue (whenever available) were obtained simultaneously so that the immunological abnormalities in the different tissues of the same

Received_for publication 10 October 1974. patient could be correlated and then used as a basis of comparison between the different groups. A comprehensive immunopathological study of a given group of patients was thought to be necessary, because the different immunological abnormalities in rheumatoid arthritis have mostly been studied as individual abnormalities in relatively small groups of patients (Zvaifler, 1973; Ziff, 1973).

\section{Materials and Methods}

All patients were diagnosed on the basis of the criteria of the American Rheumatism Association by two of us (J.F.W. and S.A.). All sera, synovial biopsies, and synovial fluid were studied blindly, ie, without knowing the identity or diagnosis of the patient. Patients whose clinical diagnosis could not be firmly established have been excluded from this report. All the patients had active disease and none was under immunosuppressive therapy at the time of biopsy or at the time of collection of serum and synovial fluid.

Rheumatoid factor was determined by the Hyland quantitative macroscopic tube test (Hyland Laboratory, California, USA). 
SYNOVIAL FLUID

Synovial fluid was collected in $10 \%$ EDTA solution under aseptic conditions. Every sample was routinely analysed for its viscosity, clot formation with $5 \%$ acetic acid, total and differential cell counts, the presence of intracellular inclusions, and for the detection and recognition of micro-crystals under polarized light (Hollander and McCarty, 1972). Aliquots of synovial fluid were centrifuged $(2000 \mathrm{rpm}$ at $4^{\circ} \mathrm{C}$ for $10 \mathrm{~min}$ ). The $\mathrm{IgG}, \operatorname{IgM}$, and $\mathrm{C} 3$ (B1C/B1 A) contents of the clear cell-free synovial fluid supernatant and patients' sera were determined by radialimmunodiffusion in plates (Hyland Laboratories) using a number of reference standards supplied by the Hyland Laboratories and the World Health Organization (WHO standard 67/87). The reproducibility of results of radial immunodiffusion was confirmed as described before (Ghose, Quigley, Landrigan, and Asif, 1973). Cytocentrifuged smears of the cellular deposits, washed in phosphatebuffered saline $(0.01$ molar, $\mathrm{pH} 7 \cdot 1 \mathrm{PBS})$ were examined by immunofluorescence for intracellular IgG, IgM, IgA, C3, and fibrin as described below.

\section{SYNOVIAL BIOPSY}

Synovial tissue obtained by needle biopsy as well as pieces of synovium obtained in the course of open joint surgery were cut into blocks (about $5 \mathrm{~mm}^{3}$ ), snap frozen in a slurry of liquid nitrogen and isopentane $\left(-160^{\circ} \mathrm{C}\right)$ and stored at $-70^{\circ} \mathrm{C}$. Air-dried, unfixed $5 \mu \mathrm{m}$ cryostat sections of synovium as well as parallel sections fixed in $5 \%$ glacial acetic acid in ethanol at $-20^{\circ} \mathrm{C}$ for 15 min (Hijmans, Schuit, and Klein, 1969) were washed three times in PBS and stained by the direct immunofluorescence method using fluorescein-isothiocyanate conjugated monospecific rabbit antisera against human IgG, IgM, IgA, C3 (B1C/B1A), fibrinogen, and albumin. All antisera were obtained from Hyland Laboratories and were conjugated with crystalline fluoresceinisothiocyanate (FITC) isomer I (Baltimore Biological Laboratory, Baltimore, Maryland). For the detection of anti-IgG activity, immunoelectrophoretically pure human IgG (Mann Research Laboratories, New York) was conjugated with fluorescein-isothiocyanate. Conjugates were freed of overlabelled globulin molecules by passing them through a column of DEAE cellulose (Riggs, Loh, and Eveland, 1960), and only those conjugates having dye protein ratios varying from 1.3 to 4.5 were used. All antisera gave a single line on immunoelectrophoresis against normal human serum both before and after labelling. Fluorescein-isothiocyanate-lacelled human IgG was aggregated by heating at $63^{\circ} \mathrm{C}$ for $10 \mathrm{~min}$ just before use (Munthe and Natvig, 1972). Specificity of immunofluorescence was established by
(1) the absence of staining of cryostat sections of normal human synovium (obtained at necropsy or. from surgically amputated limbs) by these conjugated $\overrightarrow{\vec{\rho}}$ antisera and by the aggregated IgG; (2) the absence? of staining of sections of affected synovium after absorption of the fluoresceinated antisera as ap-产 propriate with the relevant immunoglobulin fraction,,$\widehat{\infty}$ fresh normal human serum, or human plasma 0 fractions I (fibrinogen) and V (albumin); (3) the es absence of staining of affected synovium with $\vec{b}$ fluoresceinated rabbit antigoat or rabbit antihorseglobulin; (4) the absence or inhibition of staining after 'blocking' of specific staining by prior exposureof sections to non-labelled antibodies (Ghose, Nairn? and Fothergill, 1962). To avoid any possible reactionoo between the rabbit immunoglobulirs used and rheumatoid factor in the synovium under test, allo sections were exposed several times to heat-o aggregated rabbit IgG before the application of fluoresceinated rabbit antisera (Tursi, Trizio, and $\vec{T}$ Bonomo, 1970).

The findings of direct immunofluorescence stain $-\frac{\bar{c}}{2}$ ing were further confirmed by the sandwich method treating sections first with unconjugated reagents and then with fluoresceinated goat antirabbit globutint with proper controls (Ghose et al, 1973; McGiven Ghose, and Nairn, 1967). The 'sandwich' immu诤 fluorescence method was used also for the detection of antinuclear factor using undiluted and diluted sera (McGiven et al, 1967; McGiven and Ghose, 1968)융 Complement fixation by antinuclear factor was determined by the same method using fresh group $\overrightarrow{\vec{b}}$ AB normal human serum as the source of comple 3 ment (McGiven and Ghose, 1968). The specificity of complement binding by antinuclear factor in various. sera was assessed by the sandwich method on cryo응 stat sections of rat liver using known complement fixing antinuclear antibodies and fresh group $A B$. normal human serum as the source of complemeng or heated at $56^{\circ} \mathrm{C}$ for $30 \mathrm{~min}$ as a negative controB followed by fluoresceinated rabbit globulin agains human $\mathrm{C} 3$.

All sections of synovium showing human immuno음 globulins by the above methods also stained when treated with research standard A (kindly supplied by the World Health Organization, WHO ref. noN 68/45) for fluoresceinated antibody to humant immunoglobulins. To eliminate the possibility of the reaction of the antiglobulin reagents with dried-up serum or exudate trapped in tissue spaces, all sec $\frac{E}{\Phi}$ tions were washed for $15 \mathrm{~min}$ in three changes o⿷ PBS before exposure to the reagents. In addition; parallel sections from the lesion showing immuno $\overline{0}$ globulin deposits were washed overnight at $4^{\circ} \vec{\phi}^{\circ}$ either with PBS or acid-citrate buffer $(0.02 \mathrm{M}$; pF $3 \cdot 2)$ to elute globulin (Ghose et al, 1973). Sections 
washed in the acid buffer were washed again in PBS for $30 \mathrm{~min}$ to adjust the $\mathrm{pH}$ before staining for immunoglobulin. All sections washed with PBS retained extracellular clumps of immunoglobulin, whereas those washed with citrate buffer lost most of their immunoglobulin content. The details of immunofluorescence methods and further controls have been recently discussed (Ghose et al, 1973; Ghose, Landrigan, and Asif, 1974; Ghose, Landrigan, Killeen, and Dill, 1974).

A part of every biopsied synovial tissue was fixed in $10 \%$ buffered formalin and embedded in paraffin, and sections were stained with haematoxylin and eosin, Masson's trichrome (for collagen), elastic Van Gieson (for elastic fibres), Congo red for amyloid, periodic acid-Schiff (for polysaccharides), and methyl green and pyronin (for plasma cells). After immunofluorescence examination all sections were fixed in $10 \%$ formalin and stained with eosin and haematoxylin (Ghose et al, 1973).

\section{Results}

\section{IMMUNOGLOBULINS AND C 3 IN SYNOVIAL}

\section{BIOPSIES}

The results of immunohistological examination of synovial biopsies are presented in table I. The incidence of the interstitial distribution of the various immunoglobulin classes and C 3 in synovial biopsies is based exclusively on observations using unfixed cryostat sections. Cryostat sections of synovium fixed in $5 \%$ glacial acetic acid in ethanol were used only for the identification of immunoglobulins inside plasma cells (Hijmans et al, 1969). Unfixed sections of 10 out of 13 biopsies from seropositive rheumatoid arthritis patients showed extracellular clumps of IgG, IgM, and C3, and in seven IgA could also be detected in clumps. In one synovium containing clumps of IgG and IgM, no C3 could be detected. Four of the seven patients showing clumps of IgG,
IgM, IgA, and C3 had antinuclear activity in serum. Two of these patients had antinuclear activity both in the IgG and IgM fractions, one in the IgM fraction, and the other in the IgG, IgM, and $\operatorname{IgA}$ fractions. Of the eight biopsies from seronegative rheumatoid arthritis patients only two contained extracellular clumps of $\operatorname{IgG}, \operatorname{IgM}, \operatorname{IgA}$, and $\mathrm{C} 3$, and in one clumps containing IgG, IgM, and C3 could be detected. The serum of the last patient showed antinuclear activity both in the IgG and IgM fractions. Deposits of immunoglobulin and C3 were found in the wall of some of the vessels and in the perivascular areas, the interstitial spaces in the deeper layers of the synovium, and in the cytoplasm of large mononuclear cells with ample cytoplasm (probably macrophages). In the interstitium immunoglobulins were distributed either as small scattered foci (fig 1), large globular masses (fig 2), or as linear deposits along layers of collagenous tissue. In consecutive serial sections stained for $\operatorname{IgG}, \operatorname{IgM}, \operatorname{IgA}$, and $\mathrm{C} 3, \mathrm{C} 3$ staining was located mostly in those areas which contained IgG. No significant difference was found between seropositive and seronegative cases of rheumatoid arthritis either in the amount or distribution pattern of the immune complexes. Thirty-nine of the 50 synovial biopsies from osteoarthritis patients had no detectable extracellular immunoglobulins and/or C3. One biopsy showed small scattered perivascular clumps containing IgG, $\operatorname{IgM}, \operatorname{IgA}$, and $\mathrm{C} 3$, another $\operatorname{IgG}, \operatorname{IgM}$, and $\operatorname{IgA}$ mainly inside large macrophages; seven showed perivascular deposits of $\operatorname{IgA}$ only and one sparse perivascular deposits of IgG only. Biopsy from another osteoarthritis patient who had antinuclear activity (anti-DNA protein) in the IgG fraction showed scattered small homogenous masses covered with IgG $+\mathrm{C} 3$ in the interstitium. One patient with chronic non-specific traumatic synovitis (rheumatoid factor and antinuclear factor negative), showed scattered perivascular clumps containing IgG, IgM,

\begin{tabular}{|c|c|c|c|c|c|c|c|c|c|c|c|}
\hline & $\begin{array}{l}\text { Total } \\
\text { No. } \\
\text { Examined }\end{array}$ & $\begin{array}{l}\mathrm{Ig} / \mathrm{C3} \\
\text { Not } \\
\text { Detected }\end{array}$ & $\begin{array}{l}\operatorname{Ig} \boldsymbol{G}+ \\
\mathbf{I g} \boldsymbol{M}+ \\
\mathbf{I} \boldsymbol{A}+\end{array}$ & $\begin{array}{l}\operatorname{Ig} G+ \\
\operatorname{Ig} M+ \\
\operatorname{Ig} A\end{array}$ & $\begin{array}{l}\operatorname{Ig} G+ \\
\lg M\end{array}$ & $\underset{I g M}{\operatorname{Ig} G}+$ & $\begin{array}{l}\text { IgG } \\
\text { Only }\end{array}$ & $\begin{array}{l}\text { IgA } \\
\text { Only }\end{array}$ & $\begin{array}{l}I g G \\
+C 3\end{array}$ & Fibrin & $\begin{array}{l}\text { Ig-con- } \\
\text { taining } \\
\text { Plasma }\end{array}$ \\
\hline $\begin{array}{l}\text { Rheumatoid arthritis } \\
(\mathbf{R F}+) \\
\text { Rheumatoid arthritis }\end{array}$ & $13(4)$ & $2(0)$ & 7 (4) & $\mathbf{0}$ & 3 & 1 & 0 & 0 & 0 & 12 & 12 \\
\hline$(\mathbf{R F}-)$ & $8(1)$ & $5(0)$ & 2 & 0 & 1 (1) & $\mathbf{0}$ & 0 & 0 & 0 & 4 & 5 \\
\hline Osteoarthritis & $50(4)$ & 39 (1) & $1(1)$ & $1(1)$ & 0 & 0 & 1 & 7 & $1(1)$ & 24 & 12 \\
\hline Avascular necrosis & $2(0)$ & $2(0)$ & 0 & $\mathbf{0}$ & 0 & 0 & 0 & $\mathbf{0}$ & 0 & 0 & 0 \\
\hline Traumatic arthritis & $4(0)$ & $3(0)$ & $1^{1}$ & 0 & 0 & 0 & 0 & $\mathbf{0}$ & 0 & 3 & 3 \\
\hline
\end{tabular}

Table I Distribution of various immunoglobulin classes and C3 in synovial biopsies

\footnotetext{
${ }^{1}$ Raised serum SGOT and immunoglobulins.

Numbers within brackets denote the number of patients who had ANF in serum.

$\mathbf{R F}+, \mathbf{R F}-$, seropositive and seronegative rheumatoid arthritis respectively.
} 


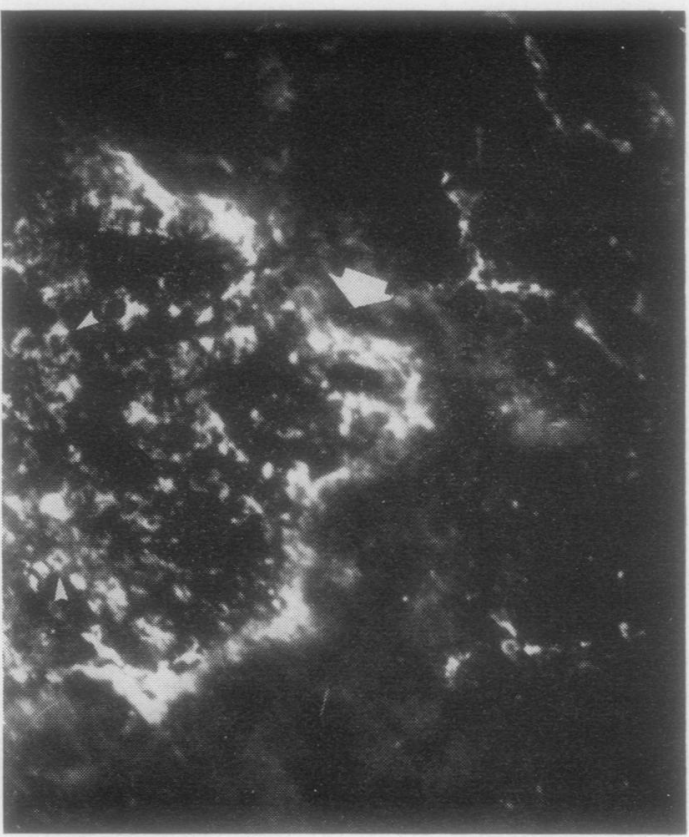

Fig 1 Fluorescence photomicrograph of an unfixed cryostat section of synovium from a seropositive rheumatoid arthritis patient showing deposits of $I g G$ in the wall of a small vessel and perivascularly (marked with a large arrow), scattered extracellular IgG clumps and mononuclear cells containing IgG (marked with small arrows). $\times 240$

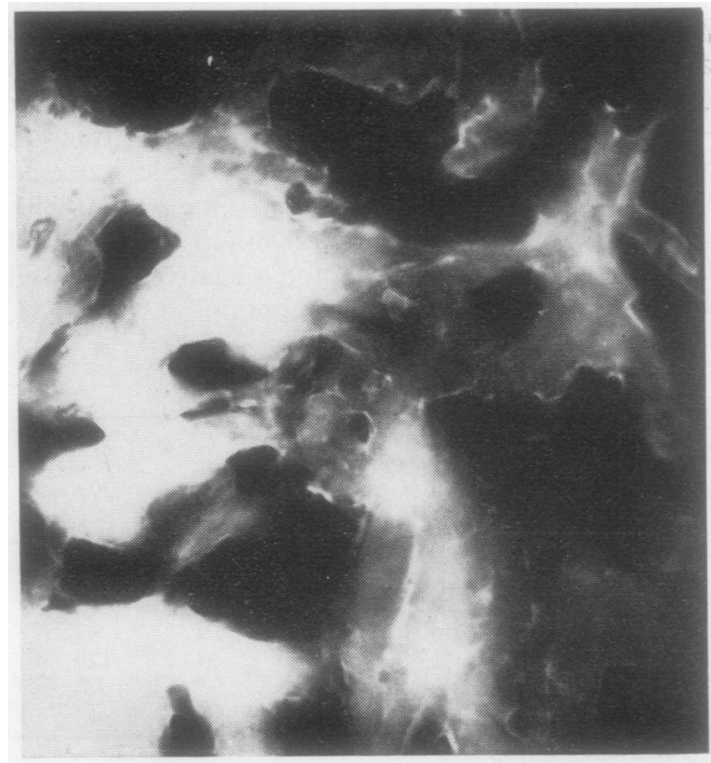

Fig 2 A parallel section of the same synovium showing large interstitial deposits of IgM and linear staining of collagenous tissue. $\times 240$

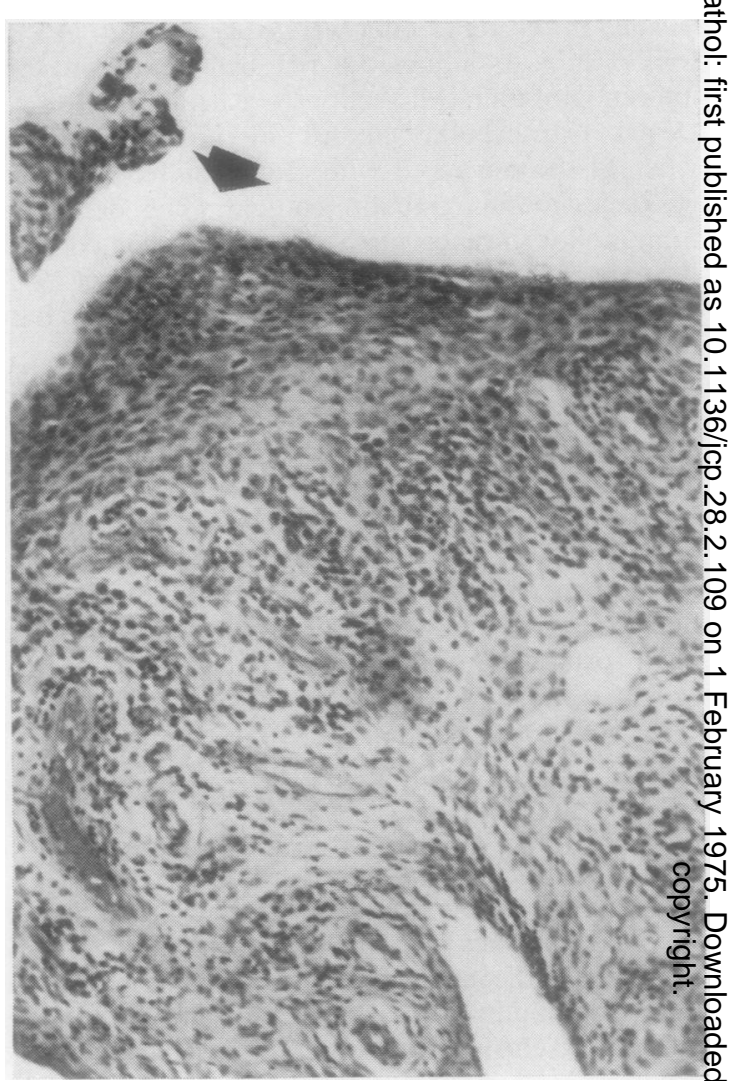

Fig 3 Photomicrograph of a paraffin section of synovial biopsy from a tissue block parallel to the one used in figures 1 and 2. Prominent lymphocytic and plasma cell infiltration and hyperplasia of the synovial lining cells (marked with an arrow) can be seen. $\times 190$

IgA, and C3. The amount of immune complex in the rheumatoid arthritis patients appeared to be mores than in those without rheumatoid arthritis. Whereaso in the rheumatoid arthritis patients immune com plexes could usually be found in all the three sites? ie, scattered in the interstitium, in the wall of some of the vessels, and the perivascular areas and inside phagocytes, the deposits of immunoglobulin in un 0 affected patients were mostly distributed perivascu స్ట larly only and occasionally inside phagocytes. $\mathrm{Ag}_{\mathrm{O}}$ gregated IgG was bound by all the synovium from seropositive and in two of the three seronegative rheumatoid arthritis patients who had deposits of IgG and IgM in the affected synovium. Plasma cells containing immunoglobulins and deposits of fibriro were commoner in the synovium from rheumatoid and traumatic arthritis patients than in the biopsies from patients with osteoarthritis. 
INCLUSIONS IN SYNOVIAL FLUID

POLYMORPHONUCLEAR LEUCOCYTES

The incidence of polymorphonuclear cells containing immunoglobulins and C3 in synovial fluid is presented in table II.

The synovial fluid polymorphonuclear leucocytes from all the 26 seropositive rheumatoid arthritis patients contained immunoglobulins with or without C3. Eighteen out of 23 seronegative rheumatoid arthritis patients had immunoglobulins with or without $\mathrm{C} 3$ in the leucocytes of the synovial fluid. Although none of the polymorphonuclear leucocytes in synovial fluid from osteoarthritis (six patients), Reiter's syndrome (one patient), and gout (two patients), showed any immunoglobulin or C3, in all the three patients suffering from arthritis associated with systemic lupus erythematosus the polymorphonuclear leucocytes contained $\operatorname{IgG}, \operatorname{IgM}$, and $\operatorname{IgA}$ and, in two of the three patients suffering from psoriasis with polyarthritis IgG, IgM, and C3. In the remaining psoriasis patient and the one patient who had arthritis associated with sarcoidosis the polymorphonuclear leucocytes contained IgG, IgM, IgA, and C3. In the patient with septic arthritis polymorphonuclear leucocytes in the synovial fluid contained IgG. All the three patients with systemic lupus erythematosus had anti-DNA and anti-DNA protein antibodies in their serum. No other patient in the non-rheumatoid arthritis group had antinuclear factor in serum.

Binding of aggregated IgG to synovial leucocytes could be demonstrated in nine of the 26 samples of synovial fluid from seropositive rheumatoid arthritis patients. Intraleucocytic IgM could also be demonstrated in all these samples. Aggregated IgG could be bound by the synovial fluid leucocytes from five seronegative patients. Both IgG and IgM could be detected in the synovial fluid leucocytes from four of these patients but only IgG and C3 inside those leucocytes of the remaining patient (fig 4). However, it was not possible to find out whether the synovial fluid leucocytes from the last patient also reacted with aggregated reduced and alkylated IgG which does not bind to complement (Munthe and Natvig, 1972).

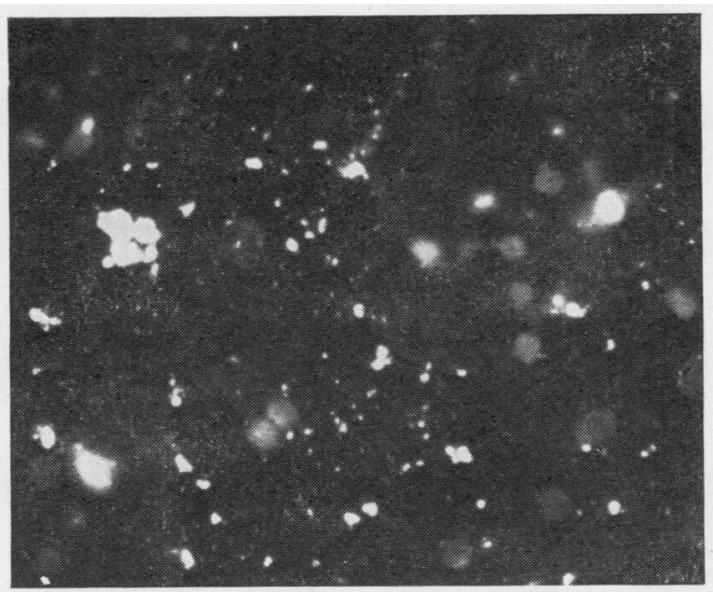

Fig 4 Fluorescence photomicrograph of a cytocentrifuge smear of synovial fluid leucocytes from a seronegative rheumatoid arthritis patient showing the binding of fluoresceinated aggregated IgG to some of the polymorphonuclear leucocytes. Only IgG and C3 could be detected in the polymorphonuclear leucocytes of this patient. Faint outlines of those leucocytes which did not bind appreciable amounts of aggregated IgG can be seen in the background. $\times 400$

\begin{tabular}{|c|c|c|c|c|c|c|c|c|c|}
\hline & $\begin{array}{l}\text { Total } \\
\text { No. } \\
\text { Examined }\end{array}$ & $\begin{array}{l}\text { Intra- } \\
\text { PMN } \\
\text { Ig/C3 Not } \\
\text { Detectable }\end{array}$ & $\begin{array}{l}\operatorname{Ig} G+M \\
+A+ \\
C 3\end{array}$ & $\begin{array}{l}I g G+M \\
+C 3\end{array}$ & $I g G+M$ & $\begin{array}{l}\operatorname{Ig} G+A \\
+C 3\end{array}$ & $\begin{array}{l}I g G+M \\
+A\end{array}$ & $\begin{array}{l}I g G \\
C 3\end{array}$ & IgG Only \\
\hline Rheumatoid arthritis $(\mathbf{R F}+)$ & $26(5)^{1}$ & 0 & $7(5)$ & 15 & 2 & 1 & 0 & 1 & 0 \\
\hline Rheumatoid arthritis (RF -) & $23(1)^{2}$ & 5 & 10 & 5 & 2 & 0 & 0 & $1(1)$ & 0 \\
\hline Osteoarthritis & 6 & 6 & 0 & 0 & 0 & 0 & 0 & 0 & 0 \\
\hline Reiter's syndrome & 14 & 1 & $\mathbf{0}$ & 0 & 0 & 0 & 0 & 0 & 0 \\
\hline Systemic lupus & $3(3)$ & $\mathbf{0}$ & 0 & 0 & 0 & 0 & $3(0)$ & 0 & 0 \\
\hline Psoriasis & $3(0)$ & $\mathbf{0}$ & 1 & 2 & 0 & 0 & 0 & 0 & 0 \\
\hline Gout & 2 & 2 & 0 & 0 & 0 & 0 & 0 & 0 & 0 \\
\hline Others $^{5}$ & $4(0)$ & 2 & $1^{3}$ & 0 & 0 & 0 & 0 & 0 & $1^{6}$ \\
\hline
\end{tabular}

Table II Distribution of various immunoglobulins and C3 in synovial fluid polymorphonuclear leucocytes

${ }^{1}$ S.F. from 20 of these patients contained RF and four of the five ANF positive patients contained ANF.

${ }^{2}$ S.F. of this patient contained ANF.

sSarcoid.

'The serum and S.F. of this patient had low titre (1/40) of RF, but no ANF.

${ }^{5}$ Two traumatic arthritis, one arthritis with sarcoidosis, one polyarthritis associated with psoriasis

Septic arthritis.

Numbers within parentheses denote the number of patients who had ANF in their serum. 
Twenty of the synovial fluids from this group of 26 seropositive rheumatoid arthritis patients contained rheumatoid factor. Four of the five seropositive and the one seronegative rheumatoid arthritis patients who had antinuclear factor in the serum also had it in synovial fluid.

IMMUNOGLOBULINS, C 3, AND LEUCOCYTES IN SYNOVIAL FLUID

The mean levels of IgG, IgM, and C3 in the simultaneously obtained samples of serum and synovial fluid from 26 patients with rheumatoid arthritis and 18 without (all were negative for rheumatoid factor except one with Reiter's syndrome) are presented in table III. Though there is no difference in the mean levels of IgG, IgM, or C3 in the serum or synovial fluid between those with and those without rheumatoid arthritis, the level of $\mathrm{C} 3$ in the synovial fluid of seropositive patients $(42 \pm 4 \cdot 55)$ is significantly lower than the level of $\mathrm{C} 3$ in the synovial fluid from patients without rheumatoid arthritis $(64 \pm 8.03)$. There was no significant difference in the $\mathrm{C} 3$ level of the 18 seropositive patients $(42 \pm 4.55)$ and that in the synovial fluid from the eight seronegative patients $(52 \pm 10.05)$. Synovial fluid from two seropositive patients also had antinuclear activity. None of the samples from the seronegative patients had antinuclear factor.

In patients with a $\mathrm{C} 3$ level less than $60 \mathrm{mg} / \mathrm{ml}$ in synovial fluid, there were more leucocytes in fluid from patients with rheumatoid arthritis (20 750 \pm $\left.5187 / \mathrm{mm}^{3}\right)$ than in fluid from those without $(9000 \pm$ $2400 \mathrm{~mm}^{3}$ ); however, this difference between the groups disappeared when the $\mathrm{C} 3$ level in synovial fluid was more than $60 \mathrm{mg} / \mathrm{ml}(16400 \pm 2400$ and $15800 \pm 5900 / \mathrm{mm}^{3}$ respectively).

Twenty-five (including five seronegative cases) of the 26 patients with rheumatoid arthritis had lower levels of $\mathrm{C} 3$ in synovial fluid than in serum. Twentytwo of these samples could be examined for the

\begin{tabular}{|c|c|c|}
\hline \multicolumn{3}{|c|}{ Quantities of Immunoglobulins and C3 in Serum and S.F. $(\mathrm{mg} / 100 \mathrm{ml}$} \\
\hline & $\begin{array}{l}\text { RA } \\
\text { (Total Samples-26) }\end{array}$ & $\begin{array}{l}\text { Non-RA } \\
\text { (Total Samples-18) }\end{array}$ \\
\hline $\begin{array}{l}\text { IgG }>\text { Serum } \\
\text { S.F. }\end{array}$ & $\begin{array}{l}R F+18 \text { RF }-8 \\
1850 \cdot 6 \pm 241 \cdot 66 \\
1018 \cdot 5 \pm 142 \cdot 53\end{array}$ & $\begin{aligned} 2401.6 & \pm 508.49 \\
882.8 & \pm 150.9\end{aligned}$ \\
\hline $\begin{array}{l}\text { IgM }=\text { Serum } \\
\text { S.F. }\end{array}$ & $\begin{aligned} 174 \cdot 8 & \pm 44 \cdot 8 \\
70 \cdot 26 & \pm 19 \cdot 8\end{aligned}$ & $\begin{array}{c}109 \cdot 83 \pm 17 \cdot 36 \\
73 \cdot 0 \pm 25 \cdot 66\end{array}$ \\
\hline $\begin{array}{ll}\text { C3 }>\text { Serum } \\
\text { S.F. }\end{array}$ & $\begin{aligned} 132 \cdot 23 & \pm 8.52 \\
46.84 & \pm 4 \cdot 37^{1}\end{aligned}$ & $\begin{array}{c}151.22 \pm 16.45 \\
64.0 \pm 8.03\end{array}$ \\
\hline \multicolumn{3}{|c|}{$\begin{array}{r}1 \text { Mean S.F. C3 level in RF }+42 \pm 4.55 \\
\text { RF }-52 \pm 10.55\end{array}$} \\
\hline \multicolumn{3}{|c|}{$\begin{array}{l}\text { Table III Mean concentrations }(\mathrm{mg} / 100 \mathrm{ml} \pm S E) \text { of } \\
\text { IgG, IgM and C3 in paired samples of serum and } \\
\text { synovial fluid from patients suffering from rheumatoid } \\
(R A) \text { and other types }(\text { non- } R A) \text { arthritis }\end{array}$} \\
\hline
\end{tabular}

presence of $\mathrm{C} 3$ in the leucocytes. Smears from all these 22 samples, including samples from five seronegative cases, had leucocytes containing C3. The remaining patient with rheumatoid arthritis had a higher C3 level in synovial fluid than in serum. The smears of synovial fluid did not show any C3containing polymorphonuclear neutrophil leucocytes $\left(21800 \mathrm{~mm}^{3}\right)$. She had active seropositive disease and was not receiving any immunosuppressive के therapy when samples were collected. Seventeen out of $\vec{\circ}$ 18 patients without rheumatoid arthritis had a lower C3 level in the synovial fluid than in serum. Synovial fluid leucocytes from 12 of these patients had smears examined for $\mathrm{C} 3$ and four of these smears (three from patients with polyarthritis associated with psoriasis $\underset{\infty}{N}$ and one with sarcoidosis) revealed $\mathrm{C} 3$-containing leucocytes. One patient with arthritis and deposits $\vec{\circ}$ of calcium pyrophosphate crystals had a higher C3 level in synovial fluid than in serum. The fluid had too few $\left(125 \mathrm{~mm}^{3}\right)$ leucocytes to allow of any study of intracytoplasmic C3.

However, when the relative concentrations of immunoglobulins in serum and synovial fluid and the permeability of the synovium were taken into account (Pruzanski, Russell, Gordon, and Ogryzlo 1973), the $C 3$ level was lower in synovial fluid conof pared with that in serum only in nine patiens. (including two seronegative patients, both of who were also negative for antinuclear factor) of these 25 . patients with rheumatoid arthritis; in the remaining 16 patients the $C 3$ level in synovial fluid was no $\unrhd$ different from that in serum when the relative con- $\overrightarrow{\vec{B}}$ centrations of IgG and IgM in serum and synovial fluid were taken into account. These nine patients as a group had the highest mean leucocyte count in the synovial fluid $\left(23594 \pm 9526 \mathrm{~mm}^{3}\right)$. Only three of the 18 patients without rheumatoid arthritis had a lower $\mathrm{C} 3$ level in the synovial fluid. All had a relatively high level of serum IgG-9000,5800, and $3300 \mathrm{mg} / 100 \mathrm{ml}$. The patient with $9000 \mathrm{mg} / 100 \mathrm{ml}$ of $\frac{0}{3}$ IgG in serum was suffering from systemic lupus erythematosus, had a high titre of antinuclear factor $\frac{5}{5}$ in serum, and, at the time when samples were ob- $\frac{D}{O}$ tained, was suffering from what was diagnosed clinically as infectious mononucleosis. The synovial $N$ fluid from this patient contained a large number of lymphocytes, plasma cells, and a few polymorpho- $N$ nuclear containing IgG, IgM, and IgA but no $\mathrm{C} 3 \mathrm{\omega}$ was seen inside these cells. The patient with? $5800 \mathrm{mg} / 100 \mathrm{ml}$ of serum IgG was suffering from Reiter's syndrome, did not have any antinuclear $\Phi_{\mathscr{C}}$ factor in serum, but had rheumatoid factor in a low titre $(1 / 80)$. The leucocytes in synovial fluid from $\frac{T}{1}$ this patient $\left(32500\right.$ per $\left.\mathrm{mm}^{3}\right)$ contained no intra- $\frac{\mathrm{O}}{\mathbb{\Phi}}$ cellular Ig or C3. The patient with $3300 \mathrm{mg} / 100 \mathrm{ml} \stackrel{\mathrm{P}}{\mathbb{D}}$ of serum IgG had systemic lupus erythematosus with 
a high titre for antinuclear factor. A small proportion of polymorphonuclear in the synovial fluid of this patient contained IgG, IgM, and IgA but no C3.

Six of the patients with rheumatoid arthritis had a higher level of IgG in synovial fluid than in serum, though the level of IgM was less than half of that in serum. Five of these six patients were seronegative. Four cases from this group of patients with rheumatoid arthritis had higher levels of IgM in synovial fluid than in serum, although the level of IgG in the serum was more than double that in synovial fluid. All these patients were negative for rheumatoid factor. This suggests local synthesis of IgG and IgM in the synovium of these seronegative and seropositive groups of patients respectively.

ANTINUCLEAR AND RHEUMATOID FACTORS

IN SERUM AND SYNOVIAL FLUID

In a separate group of patients, synovial fluid and sera from 36 seropositive and 24 seronegative patients with rheumatoid arthritis and 39 patients with osteoarthritis were tested for antinuclear and rheumatoid factors. Six of 36 sera from seropositive patients and two of 24 from those of seronegative patients with rheumatoid arthritis and two of 39 sera from patients with osteoarthritis had antinuclear factor. Activity could be detected in the synovial fluid of the four seropositive patients with antinuclear factor in serum and in the synovial fluid of one patient without antinuclear factor in serum but in the synovial fluid of none of the seronegative patients. Antinuclear factor in four of the six positive sera from the positive group for rheumatoid factor and one serum from the negative group but none from the osteoarthritis group fixed complement.

Rheumatoid factor could be detected in the synovial fluid of 32 of 36 seropositive patients for rheumatoid factor, of two of 24 patients seronegative for rheumatoid factor but in none of the patients with osteoarthritis. Tenfold concentration of the synovial fluid immunoglobulin (Ghose and Woodbury, 1972) revealed antinuclear factor in the synovial fluid of the two remaining patients with rheumatoid arthritis with antinuclear factor in serum and in that of two further seropositive patients without antinuclear factor in serum or in the tenfold concentrated serum immunoglobulin. Concentration of the synovial fluid immunoglobulins from seronegative rheumatoid arthritis patients also showed antinuclear factor in the concentrated synovial fluid from two patients whose serum did not have antinuclear factor. From the osteoarthritis group there was enough synovial fluid available for concentration of immunoglobulin from eight patients only. None of the concentrated immunoglobulins from these fluids showed activity of antinuclear or rheumatoid factors.

\section{Discussion}

Bonomo, Tursi, Trizio, Gillardi, and Dammacco (1970) detected IgG-BlC complexes in synovial biopsies from all the seven seropositive and three seronegative patients for rheumatoid arthritis studied by them, and IgG, rheumatoid factor complexes in the affected synovium of the seven seropositive patients; however, we could not detect tissue-bound immunoglobulins with or without $\mathrm{C} 3$ in the synovial biopsy from two of 13 seropositive and five of eight seronegative patients. Fish, Michael, Gewurz, and Good (1966) also failed to detect immunoglobulins and $\mathrm{C} 3$ in the affected synovium of one seronegative 'juvenile' rheumatoid arthritis patient. Though small biopsies might not be representative, the incidence of synovium-bound immunoglobulins with or without $\mathrm{C} 3$ appears to be higher in seropositive patients than in seronegative patients. The detection of clumps of IgM in the synovium of the three seronegative patients and inside synovial leucocytes from 17 of 23 seronegative patients is interesting. Clumps of IgM were detected in the affected synovium of two seronegative juvenile and one seronegative adult rheumatoid arthritis patient by Fish et al (1966). Cracchiolo and Goldberg (1972) also detected rheumatoid factor activity in the synovial eluate from one seronegative patient. They also observed antinuclear factor in the synovial eluate of four patients with rheumatoid arthritis whose serum did not have antinuclear activity. Our own results for the presence of rheumatoid factor in the synovial fluid of seronegative patients and for antinuclear factor in synovial fluid of patients without antinuclear factor in serum support the hypothesis of Cracchiolo and Goldberg (1972) that antinuclear and/or rheumatoid factor might either be selectively sequestrated or locally synthesized in the joints affected by rheumatoid arthritis. Selective sequestration of circulating proteins in synovial fluid is now well documented (Zvaifler, 1973). However, nonspecific phagocytosis of IgM in the inflammatory exudate by polymorphonuclear might also explain the intracellular IgM in the synovial fluid from seronegative patients with rheumatoid and traumatic arthritis.

Though previous studies by immunofluorescence (Fish et al, 1966; Bonomo, Tursi, Trizio, Gillardi, and Dammacco, 1970) failed to detect extracellular deposits of $\operatorname{IgA}$, deposits of $\operatorname{IgA}$, together with $\operatorname{IgG}$, IgM, and $\mathrm{C} 3$ in seven seropositive and two seronegative patients with rheumatoid arthritis described in this report is especially interesting because anti- $\gamma$ globulin activity has been detected in IgA (Heimer and Levin, 1964; Torrigiani and Roitt, 1967) and IgA has also been eluted from affected synovium 
from rheumatoid arthritis patien's (Cracchiolo and Goldberg, 1972). The patient with traumatic arthritis whose synovium had bound IgG, IgM, and IgA and C3 histologically showed non-specific chronic synovitis with areas of haemorrhage. Deposits of all these three immunoglobulins and $\mathrm{C} 3$ have been described in the affected synovium of traumatic arthritis patients by Fish et al (1966) and Cracchiolo and Goldberg (1972). All the three osteoarthritis patients who had more than one class of immunoglobulin or IgG and $\mathrm{C} 3$ in the affected synovium had antinuclear factor in the serum. These results, therefore, show that though synovial deposits of immunoglobulins with or without $\mathrm{C} 3$ are found most commonly in seropositive rheumatoid arthritis, such tissue-bound immunoglobulins are sometimes also found in traumatic and other types of arthritis, especially in the presence of antinuclear factor in the serum.

The demonstration of immunoglobulins, with or without C3, and especially of IgM inclusions inside synovial fluid polymorphonuclear leucocytes in 24 of 26 seropositive and in 17 of 23 seronegative rheumatoid arthritis patients, in all the three patients with systemic lupus erythematosus and psoriatic polyarthritis, and in one patient with sarcoidosis support the contention of Vaughan, Barnett, Sobel, and Jacox (1968) that though such inclusions are found in most seropositive patients and are also common in seronegative rheumatoid arthritis, they are not an exclusive feature of the disease. Inclusions inside synovial and peripheral blood polymorphonuclears in another patient with sarcoidosis was observed by Vaughan et al (1968), and this is especially interesting because we were able to detect $\operatorname{IgG}, \operatorname{IgM}, \operatorname{IgA}$, and $\mathrm{C} 3$ bound to the lesions of three patients with pulmonary sarcoidosis (Ghose et al, 1974).

The serum levels of IgG in groups both with and without rheumatoid arthritis reported in this study are somewhat high. In the latter group, this resulted from the inclusion in this group of patients with systemic lupus erythematosus and a few others with very high levels of serum immunoglobulin. Increased levels of IgG and IgM in rheumatoid arthritis sera have been reported by others, but this is not a consistent feature (Pruzanski et al, 1973). Our observations on the low C3 level in the synovial fluid of seropositive patients and increased leucocyte counts in the synovial fluid of patients with a lower level of C3 is consistent with similar findings by other groups (Vaughan et al, 1968; Britton and Schur, 1971; Ruddy and Austen, 1973; Zvaifler, 1973). Of special interest was the demonstration by immunofluorescence of binding of aggregated IgG to the IgG and C3-containing leucocytes from a seronegative patient. This further supports the hypothesis that IgG with anti-IgG activity can bind C3 and thus might play an important role in the pathogenesis of rheumatoid arthritis (Winchester, Agnello, and Kunkel, 1970); complement-fixing antinuclear factor occasionally detected in the synovial fluid of some of these patients might similarly add to tissue damage (Zvaifler and Martinez, 1971). However, our recent demonstration that arthritis can be produced in C5-deficient SWR mice by injections of human rheumatoid arthritis synovium homogenate (Crocker, Ghose, Rozee, Woodbury, and Stevenson, 1974) suggests that joint lesions can be produced without the participation of the classical complement cascade.

This investigation was supported by a grant from the Canadian Arthritis and Rheumatism Society. We wish to acknowledge the participation of the staff of the Dalhousie Rheumatic Disease Unit. We are grateful to Drs R. H. Yabsley, B. J. Grogano, A. J. Buhr, D. Petrie, and T. M. F. Roberts for referring synovial biopsies for immunohistological study.

\section{References}

Bonomo, L., Tursi, A., Trizio, D., Gillardi, U., and Dammacco, 8 (1970). Immune complexes in rheumatoid synovitis: a mixed staining immunofluorescence study. Immunology, 18, 557-56

Britton, M., and Schur, P. H. (1971). The complement system 通rheumatoid synovitis. II. Intracytoplasmic inclusions क्षे immunoglobulins and complement. Arthr. and Rheum., 14. $\overline{\bar{O}}$ 87-95.

Cracchiolo III, A., and Goldberg, L. S. (1972). Elution of antiglobulins and antinuclear antibody from rheumatoid synovial membrane. Ann. rheum. Dis., 31, 186-191.

Crocker, J. F. S., Ghose, T., Rozee, K., Woodbury, J., and Stevenson, B. (1974). Arthritis, deformities, and runting in C5-deficient mice injected with human rheumatoid arthritis synovium. $J$. clin. Path., 27, 122-124.

Fish, A. J., Michael, A. F., Gewurz, H., and Good, R. A. (1966) Immunopathologic changes in rheumatoid arthritis synovium. Arthr. and Rheum., 9, 267-279.

Ghose, T., Landrigan, P., and Asif, A. (1974). Localization of immunoglobulin and complement in pulmonary sarcoid granulomas. Chest, 66, 264-268.

Ghose, T., Landrigan, P., Killeen, R., and Dill, J. (1974). Immunopathological studies in patients with farmer's lung. Clin. Allerg., 4, 119-129.

Ghose, T., Nairn, R. C., and Fothergill, J. E. (1962). Uptake of pro- 응 teins by malignant cells. Nature (Lond.), 196, 1108-1109.

Ghose, T., Quigley, J. H., Landrigan, P. L., and Asif, A. (1973). $D$ Immunoglobulins in aqueous humour and iris from patients with endogenous uveitis and patients with cataract. Brit. J. Ophthal., 57, 897-903.

Ghose, T., and Woodbury, J. F. L. (1972). Possible immunological o mechanisms of tissue injury in joint diseases. In Immune $\mathrm{N}$ Reactions and Experimental Models in Rheumatic Diseases, edited by D. A. Gordon, pp. 102-105. University of Toronto $\boldsymbol{\omega}$ Press, Toronto.

Heimer, R., and Levin, F. M. (1964). Gamma ${ }_{14}$ and gamma rheumatoid factors. Arthr. and Rheum., 7, 738.

Hijmans, W., Schuit, H. R. E., and Klein, F. (1969). An immunofluorescence procedure for the detection of intracellular $\mathscr{S}$ immunoglobulins. Clin. exp. Immunol., 4, 457-472.

Hollander, J. L., and McCarty, D. J. (1972). Arthritis and Allied $\square$ Conditions: A Text Book of Rheumatology. Lea and Febiger, $\bar{O}$ Philadelphia.

McGiven, A. R., and Ghose, T. (1968). Antinuclear factor in NZB/ NZW mice: incidence and in vitro effects. Clin. exp. Immunol. (D) 3. 657-663. 
McGiven, A. R., Ghose, T., and Nairn, R. C. (1967). Autoantibodies in ulcerative colitis. Brit. med. J., 2, 19-23.

Munthe, E., and Natvig, J. B. (1972). Complement-fixing intracellular complexes of IgG rheumatoid factor in rheumatoid plasma cells. Scand. J. Immunol., 1, 217-229.

Pruzanski, W., Russell, M. L., Gordon, D. A., and Ogryzlo, M. A. (1973). Serum and synovial fluid proteins in rheumatoid arthritis and degenerative joint diseases. Amer. J. med. Sci., 265, 483-490.

Riggs, J. L., Loh, P. C., and Eveland, W. C. (1960). A simple fractionation method for preparation of fluorescein-labelled gamma globulin. Proc. Soc. exp. Biol. (N.Y.), 105, 655-658.

Ruddy, S., and Austen, K. F. (1973). Activation of the complement system in rheumatoid synovitis. Fed. Proc., 32, 134-137.

Torrigiani, G., and Roitt, I. M. (1967). Antiglobulin factors in sera from patients with rheumatoid arthritis and normal subjects. Ann. rheum. Dis., 26, 334-340.
Tursi, A., Trizio, D., and Bonomo, L. (1970). An immunofluorescence mixed staining technique for the detection of IgG-rheumatoid factor and IgG-1C complexes in tissues. Clin. exp. Immunol., 6, 767-772.

Vaughan, J. H., Barnett, E. V., Sobel, M. V., and Jacox, R. F. (1968). Intracytoplasmic inclusions of immunoglobulins in rheumatoid arthritis and other diseases. Arthr. and Rheum., 11, 125-134.

Winchester, R. J., Agnello, V., and Kunkel, H. G. (1970). Gamma globulin complexes in synovial fluids of patients with rheumatoid arthritis: partial characterization and relationship to lowered complement levels. Clin. exp. Immunol., 6, 689-706.

Ziff, M. (1973). Pathophysiology of rheumatoid arthritis. Fed. Proc., 32, $131-133$.

Zvaifler, N. J. (1973). The immunupathology of joint inflammation in rheumatoid arthritis. Advanc. Immunol., 16, 265-336.

Zvaifler, N. J., and Martinez, M. M. (1971). Antinuclear factors and chronic articular inflammation. Clin. exp. Immunol., 8, 271-278.

\section{The January 1975 Issue}

\section{THE JANUARY 1975 ISSUE CONTAINS THE FOLLOWING PAPERS}

Excess intravascular coagulation complicating low cardiac output T. C. MCN. INGLIS, G. R. BREEZE, J. STUART, L. D. ABRAMS, K. D. ROBERTS, AND S. P. SINGH

Haematological changes in active chronic hepatitis with reference to the role of the spleen P. J. TOGHILL AND SHEILA GREEN

The influence of extraneous factors on Coulter $\mathrm{S}$ measurement of the mean corpuscular volume $M$. YOUNG AND A. C. K. LAWRENCE

A sensitive technique by differential scanning for detecting haemoglobins of fetal origin M. C. OWEN

The morphological identification of pathogenic yeasts using carbohydrate media K. R. JOSHI, D. A. BREMNER, D. N. PARR, AND J. B. GAVIN

Comparison of different media for bacteriocine typing of Proteus mirabilis R. H. GEORGE

The flora of renal haemodialysis shunt sites $M$. H. REBEL, R. VAN FURTH, P. STEVENS, LUCY BOSSCHERZONDERMAN, AND W. C. NOBLE

Titres and cross reactions of commercial antisera for the capsular typing of Klebsiella species M. W. CASEWELL

The Compu-pet 100: A versatile dispenser-diluter for the mechanization of microbiological techniques A. W. CREMER, B. MELLARS, AND E. JOAN STOKES
The relationship and significance of antibody titres as determined by various serological methods in glandular and ocular toxoplasmosis K. A. KARIM AND G. B. LUDLAM

A screening method for the detection of Brucella antibodies in human serum P. M. HINCHLIFFE, L. ROBERTSON, AND I. D. FARRELL

Intact and fragmented intracellular immunoglobulin in a case of non-secretory myeloma J. T. WHICHER, J. D. DAVIES, AND J. A. GRAYBURN

Bronchorrhoea in a case of alveolar cell carcinoma S. G. SPIRO MARIE-TERESA, LOPEZ-VIDRIERO, JANET CHARMAN, I. DAS, AND LYNNE REID

Orcein staining of hepatitis $B$ antigen in paraffin sections of liver biopsies K. P. DEODHAR, E. TAPP, AND P. J. SCHEUER

A membrane filter technique for testing disinfectants JEAN PRINCE, C. E. A. DEVERILL, AND G. A. J. AYLIFFE

Indexing and filing of pathological illustrations R. A. G. BROWN, R. S. FAWKES, AND J. SWANSON BECK

\section{Technical methods}

Oral butter fat test meal with serum nephelometry in suspected fat malabsorption S. J. BENTLEY, R. D. EASTHAM, AND R. F. LANE

A simple device for washing out radioimmunoassay tubes $K$. N. FRAYN

Letters to the Editor

Book reviews

Copies are still available and may be obtained from the PUBLISHING MANAGER, BRITISH MEDICAL ASSOCIATION, TAVISTOCK SQUARE, LONDON, WC1H 9JR, price $£ 1.05$. 